\title{
Job tasks, computer use, and the decreasing part-time pay penalty for women in the UK
}

Citation for published version (APA):

Elsayed, A. E. A., de Grip, A., \& Fouarge, D. (2014). Job tasks, computer use, and the decreasing parttime pay penalty for women in the UK. ROA. ROA Research Memoranda No. 003 https://doi.org/10.26481/umaror.2014003

Document status and date:

Published: 01/01/2014

DOI:

10.26481/umaror.2014003

Document Version:

Publisher's PDF, also known as Version of record

\section{Please check the document version of this publication:}

- A submitted manuscript is the version of the article upon submission and before peer-review. There can be important differences between the submitted version and the official published version of record.

People interested in the research are advised to contact the author for the final version of the publication, or visit the DOI to the publisher's website.

- The final author version and the galley proof are versions of the publication after peer review.

- The final published version features the final layout of the paper including the volume, issue and page numbers.

Link to publication

\footnotetext{
General rights rights.

- You may freely distribute the URL identifying the publication in the public portal. please follow below link for the End User Agreement:

www.umlib.nl/taverne-license

Take down policy

If you believe that this document breaches copyright please contact us at:

repository@maastrichtuniversity.nl

providing details and we will investigate your claim.
}

Copyright and moral rights for the publications made accessible in the public portal are retained by the authors and/or other copyright owners and it is a condition of accessing publications that users recognise and abide by the legal requirements associated with these

- Users may download and print one copy of any publication from the public portal for the purpose of private study or research.

- You may not further distribute the material or use it for any profit-making activity or commercial gain

If the publication is distributed under the terms of Article $25 \mathrm{fa}$ of the Dutch Copyright Act, indicated by the "Taverne" license above, 
Maastricht University

Research Centre for Education and the Labour Market | ROA

\title{
Job tasks, computer use, and the decreasing part-time pay penalty for women in the UK
}

\author{
Ahmed Elsayed \\ Andries de Grip \\ Didier Fouarge
}

\section{ROA Research Memorandum}

ROA-RM-2014/3

Research Centre for Education and the Labour Market Maastricht University

P.O. Box 616, 6200 MD Maastricht, The Netherlands

$\mathrm{T}+31433883647 \mathrm{~F}+31433884914$

secretary-roa-sbe@maastrichtuniversity.nl www.roa.nl 


\title{
Job tasks, computer use, and the decreasing part-time pay penalty for women in the UK
}

\author{
Ahmed Elsayed \\ Andries de Grip \\ Didier Fouarge
}

ROA-RM-2014/3*

March 2014

Research Centre for Education and the Labour Market

Maastricht University

P.O. Box 616, 6200 MD Maastricht, The Netherlands

$\mathrm{T}+31433883647 \mathrm{~F}+31433884914$

secretary-roa-sbe@maastrichtuniversity.nl

www.roa.nl

\footnotetext{
* The ROA Research Memorandum Series was created in order to make research results available for discussion, before those results are submitted for publication in journals.
} 


\section{Abstract \\ Job tasks, computer use, and the decreasing part-time pay penalty for women in the UK**}

Using data from the UK Skills Surveys, we show that the part-time pay penalty for female workers within low- and medium-skilled occupations decreased significantly over the period 1997-2006. The convergence in computer use between part-time and full-time workers within these occupations explains a large share of the decrease in the part-time pay penalty. However, the lower part-time pay penalty is also related to lower wage returns to reading and writing which are performed more intensively by full-time workers. Conversely, the increasing returns to influencing has increased the part-time pay penalty despite the convergence in the influencing task input between part-time and full-time workers. The relative changes in the input and prices of computer use and job tasks together explain more than 50 percent of the decrease in the part-time pay penalty.

JEL classification: J24, J31

Keywords: part-time work, pay penalty, job tasks, computer use

$\begin{array}{ll}\text { Ahmed Elsayed } & \begin{array}{l}\text { Andries de Grip } \\ \text { ROA }\end{array} \\ \begin{array}{ll}\text { ROA } \\ \text { P.O. Box } 616\end{array} & \begin{array}{l}\text { NL-6200 } 616 \\ \text { NL-6200 MD Maastricht }\end{array} \\ \begin{array}{l}\text { The Netherlands } \\ \text { The Netherlands }\end{array} & \begin{array}{l}\text { a.degrip@maastrichtuniversity.nl } \\ \text { and IZA, Bonn }\end{array} \\ \begin{array}{l}\text { a.mohamed@maastrichtuniversity.nl } \\ \text { and IZA, Bonn }\end{array} & \\ \text { Didier Fouarge } & \\ \text { ROA } & \\ \text { P.O. Box } 616 & \\ \text { NL-6200 MD Maastricht } & \\ \text { The Netherlands } & \\ \text { d.fouarge@maastrichtuniversity.nl } & \end{array}$

** We acknowledge the comments and suggestions of Francis Green, Daniel Hamermesh, Annemarie Künn-Nelen, Maria Zumbühl, the participants at the DUHR seminar meeting at Maastricht University, the annual INSCOPE Research for Innovation workshop at the University of Twente, the conference "Cognitive and Non-Cognitive Skills over the Life Cycle" at Maastricht University, the international conference "Inequalities, Skills, and Globalization" in Lille, France and the second international BIBB/IAB workshop T.A.S.K.S. 2 in Bonn, Germany. 
There is a growing body of economic literature that uses a task-based approach to investigate recent changes in gender wage inequality, as well as gender differences in job tasks (e.g. Black and Spitz-Oener 2010; Lindley 2012). The task-based approach has the advantage of providing direct measures of job tasks at the individual level. It can, therefore, be used to give a comprehensive characterization of changes in job content both across and within occupations, and to investigate the implication of these changes for the gender earnings gap. However, previous studies that used a task-based approach ignore that in several advanced countries a large share of the female labour force works on a part-time basis (Booth and van Ours 2013). Various studies investigated pay differences between part-time and full-time workers (e.g. Hirsch 2005; Manning and Petrongolo 2008; Mumford and Smith 2009; Connolly and Gregory 2010), but none of these studies has considered the effect of relative changes in part-time workers' computer use and job tasks on the part-time pay penalty (PTPP). We might expect that technical change driven by the continuously declining price of IT could have increased part-time workers' computer use to a level similar to that of full-time workers. This could have resulted in a relative increase in non-routine job task inputs for parttime workers and a related decrease in the PTPP. Moreover, changes in wage returns to specific job tasks which are characteristic for part-time or full-time workers could provide an explanation for the decrease in the PTPP.

Although our data do not allow for causal claims, this paper is the first to use a taskbased approach to document recent changes in the PTPP. We use data on employed women from the UK Skills Surveys of 1997 and 2006 to study relative shifts in the input of computer use and job tasks between part-time and full-time workers. In addition, we investigate the extent to which shifts in computer use and job tasks could explain changes in the PTPP. We 
limit this analysis to workers in low- and medium-skilled occupations. ${ }^{1}$ We do this because in the UK part-time workers hardly sort into high-skilled occupations (Manning and Petrongolo 2008). In high-skill occupations part-time workers are small in numbers and have human capital characteristics and job task profiles which are close to those of full-time workers. In such occupations part-time workers usually work as highly-specialized agency workers who get remunerated at a higher hourly rate than regular workers (Manning and Petrongolo 2008).

Our empirical analyses show that there has been a decrease in the PTPP over the period 1997-2006 for female workers in the low- and medium-skilled occupations in the UK. This decrease has been accompanied by a convergence in computer use, self-planning, and influencing tasks between part-time and full-time workers. ${ }^{2}$ This convergence has taken place mainly within occupations and was not due to changes in occupational segregation between part-time and full-time workers. Particularly, the convergence in computer use explains a substantial part of the decrease in the PTPP. Moreover, the change in the PTPP is also affected by changes in wage returns to job tasks performed more intensively by full-timers. While the decreasing wage returns to reading and writing have decreased the PTPP, the increasing wage returns to influencing (i.e. managerial tasks) have increased the PTPP despite the convergence in the input of influencing between part-time and full-time workers. We find that relative changes in the input and prices of computer use and job tasks explain together more than 50 percent of the wage convergence between part-time and full-time workers in low- and medium-skilled occupations.

The remainder of the paper is structured as follows. The next section discusses the related literature. Section 3 describes the data and the variables used. Section 4 documents the relative changes in wages, computer use and job tasks between part-time and full-time

\footnotetext{
${ }^{1}$ We show, however, descriptive statistics for workers in high-skilled occupations.

${ }^{2}$ The convergence in these job tasks is in line with the findings of Gallie and Zhou (2011) who showed improvement in the educational level as well as training attainments for the UK female part-time relative to male full-time workers over the period 1992-2006.
} 
workers. Section 5 uses the Oaxaca-Ransom decomposition approach to investigate whether the changes in the PTPP, computer use, and job tasks take place within or across occupations. Section 6 investigates to what extent relative changes in computer use and job tasks explain the changes in the PTPP using the decomposition approach by Juhn, Murphy, and Pierce (1991). Finally, Section 7 summarizes the findings and concludes.

\section{Related literature}

In this paper we build on the growing literature that emphasizes the relevance of changes in job tasks as well as the literature on the PTPP. Among others, Acemoglou (1998), Autor et al. (2003), Garicano and Rossi-Hansberg (2006), Spitz-Oener (2006), and Snower and Görlich (2013) have used a task-based framework to study the impact of technological and organizational changes on skill demands and wage inequality. A major advantage of this taskbased framework is the ability to analyse changes not only across but also within occupations. Black and Spitz-Oener (2010) used a task-based framework to investigate the implications of task polarisation for the job content of women in Germany. They showed that during the 1970s and the 1980s there was a concentration of women in occupations characterized by intensive routine tasks, and subsequently women experienced larger reductions in routine tasks than men. This led to greater job polarisation for women. Lindley (2012) studied the gender difference in the shifts in skill demands in the UK and showed that women lost out from technical change between 1997 and 2006 due to their lower math and literacy skills, as well as other skills required to undertake the tasks that are affected by technical change, particularly in highly-computerised industries like finance and manufacturing. However, these studies were all limited to full-time workers.

Among the female labour force in the UK, about 40 percent are employed on parttime basis (Manning and Petrongolo 2008; Paull 2008). Part-time workers are traditionally characterized by relatively low levels of general and specific skills, restricted opportunities 
for skill improvement, and poor career prospects (e.g. Gallie et al.1998; Gallie and Zhou 2011). Despite the recent improvement in the educational level as well as training participation of British part-time female workers compared to full-time male workers (Gallie and Zhou 2011), a transition to part-time work is still often accompanied by occupational downgrading (Connolly and Gregory 2008). The skill disadvantage of part-time compared to full-time workers is associated with a lower hourly wages for part-timers relative to fulltimers (Hirsch 2005). The literature on the PTPP extensively shows that being employed parttime results in a wage disadvantage (Ermisch and Wright 1993). Manning and Petrongolo (2008) showed that taking account of occupational segregation explains the PTPP to a large extent but not fully. There are, however, hardly any studies which investigate the impact of the differences in job content between part-time and full-time workers on the PTPP. One exception is the study by Hirsch (2005) who showed that the wage gap between part-time and full-time workers in the US could to a large extent be attributed to differences in job tasks between the two groups. The author used the $\mathrm{O} * \mathrm{NET}$ data which provides detailed descriptions of occupations. He showed that part-timers have generally less verbal, mathematical, and problem solving tasks than full-timers and that the inclusion of information on job characteristics could partly explain the PTPP. However, as the O*NET data assign identical values to part-time and full-time workers in the same occupation, Hirsch (2005) could not disentangle the impact of occupational segregation on the PTPP from that of individual job tasks. Moreover, the relative change over time in computer use and job tasks of part-time workers and the associated change in the PTPP have not yet been addressed in the literature.

\section{Data and descriptive statistics}

For our analyses, we use data on female workers aged 20 to 60 years old from the 1997 and 2006 waves of the UK Skills Surveys. The UK Skills Surveys are repeated surveys that 
contain cross-sectional data on employment conditions, general skills, wages, as well as occupation, industry, and firm size. More importantly, the surveys contain detailed information on workers' computer use and job tasks. We exclude self-employed workers and use a consistent sample of cases with full information on demographics, job tasks, human capital, occupations, and wages $(\mathrm{N}=3,782){ }^{3}$ Following Manning and Petrongolo (2008), we use the self-reported part-time status as our measure of part-time employment. ${ }^{4}$ In our analysis we compare the shifts in wages, computer use, and job tasks between part-time and full-time workers. A worker's wage is assessed by the self-reported gross hourly wage. In case of not being directly quoted, this variable is calculated from the gross usual weekly pay divided by the weekly hours of work.

We use two measures of computerisation. The first measure is a dummy variable that takes the value 1 if the worker uses a computer at work, and 0 otherwise. As a second measure for computerisation, we take the complexity of computer use. Computer users were asked to indicate the level of their computer use on a four-point scale (using several examples to explain the various levels). Just like Green (2012), we aggregated the lowest two levels to capture "low-level" computer use (e.g. email use, word processing, and their equivalents), and the upper two levels to capture "high-level" computer use (e.g. using statistical packages, programming, and their equivalents). The reference group is those who do not use computers at all (Green 2012).

Autor et al. (2003) have introduced the distinction between routine and non-routine tasks to study how computerisation substitutes for workers in performing routine tasks while it complements workers in performing non-routine tasks. However, the way job tasks are

\footnotetext{
${ }^{3}$ Replicating the analyses without sample restrictions gives similar pattern of results.

${ }^{4}$ The subjective measure of part-time employment is closest to the legal definition of part-time employment (Manning and Petrongolo 2008). However, when we replicate our analysis using a commonly used measure of part-time employment based on working for less than 30 hours per week (e.g. Connolly and Gregory 2008; 2009; Mumford and Smith 2009 ), we get similar results.
} 
addressed in the UK Skills Surveys makes it difficult to make such a distinction between routine and non-routine tasks (Green 2012). Job tasks in the UK skills surveys are measured through a detailed list of questions in which respondents are asked to indicate the importance of every single task on a five-point scale ranging from "essential," to "not at all important/does not apply". We follow Green (2012) and group the 32 job tasks distinguished in the UK Skills Surveys into eight generic tasks: reading and writing, math, external communication, influencing (i.e. managerial tasks), self-planning, problem solving, physical tasks, and checking. We then calculate average scores from the responses to the eight items. ${ }^{5}$ Details on the underlying job tasks are listed in Table A1 in the appendix.

As part-time workers are less likely to sort into high-skilled occupations (Manning and Petrongolo 2008), we divide the sample into (1) low- and medium-skilled occupations and (2) high-skilled occupations. We use the occupational classification by Elias and Mcknight (2001) as a basis for this division (See Table A2 in the appendix). The high-skilled occupations are the level 4 occupations. All other occupations (level 1-level 3) are referred to as the low- and medium-skilled occupations. Table 1 shows the difference in wages, computer use, and job tasks as well as other relevant variables between part-time and fulltime workers. The table shows that there is a significant PTPP in the low- and mediumskilled occupations. However, there is a part-time pay premium in the high-skilled occupations. At both occupational-skill levels, full-timers score significantly higher than parttimers in all tasks, with the exception of physical tasks. However, the difference in job tasks between part-time and full-time workers in the low- and medium-skilled occupations is more pronounced than the difference in the high-skilled occupations. The table also shows that

\footnotetext{
${ }^{5}$ Despite the difficulty to classify all eight categories of tasks into clear-cut routine vs. non-routine groups, Green (2012) states that it is fairly clear that some of these categories can be safely classified as "non-routine" (e.g. Influencing, and self-planning). However, it is hard to identify a priori which tasks are "routine."
} 
part-time workers are generally older, less educated, and less trained than full-time workers. In addition, they are more likely to be married and have children.

Table 2 shows the levels and changes in wages, job tasks, and other relevant variables between 1997-2006 for part-time and full-time workers in both the low- and medium-skilled occupations and the high-skilled occupations. In the low- and medium-skilled occupations, the table shows convergence between part-time and full-time workers in wages, computer use (particularly low level computer use), and various job tasks such as problem solving, selfplanning, and influencing. In the high-skilled occupations there are no significant differences in the relative changes in wages, computer use, and job tasks of part-time and full-time workers. However, the few observations of part-time workers in the high-skilled occupations makes it difficult to reach conclusive findings regarding relative changes in wages and job tasks. Therefore, we limit our further analyses to the low- and medium-skilled occupations.

\section{The convergence in wages, computer use, and job tasks}

To estimate changes in the PTPP and changes in job tasks between part-time and full-time workers over the period 1997-2006, we use the following two equations:

$$
\begin{aligned}
& W_{i}=\alpha+\beta_{1} P T_{i}+\beta_{2} Y 2006_{i}+\beta_{3}\left[P T_{i} * Y 2006_{i}\right]+\beta_{4} X_{i}+\varepsilon_{i} \\
& T_{i}=\varphi+\gamma_{1} P T_{i}+\gamma_{2} Y 2006_{i}+\gamma_{3}\left[P T_{i} * Y 2006_{i}\right]+\gamma_{4} X_{i}+e_{i}
\end{aligned}
$$

where $W_{i}$ is the worker's $\log$ wage and $T_{i}$ is the level of a specific task input. $P T$ is a dummy variable that takes the value 1 if the worker is a part-timer, and 0 otherwise. Y2006 is a dummy variable that takes the value 1 if the observation comes from the year 2006, and 0 otherwise. The interaction term between $P T$ and $Y 2006$ is our measure of the change in the PTPP in equation (1) and the change in job task levels between part-time and full-time workers in equation (2). $X_{i}$ is a set of control variables that includes worker's age, age squared, marital status, number of children, level of education, training participation, work 
experience, work experience squared, industry sector and occupational dummies. $\varepsilon_{i}$ and $e_{i}$ are error terms.

Table 3 shows the coefficient estimates of the change in the PTPP in the low- and medium-skilled occupations. Columns 1 and 2 show the estimates without and with controls, respectively. The table shows that there has been a significant convergence in wages between part-time and full-time workers in the low- and medium-skill occupations. The PTPP in these occupations decreased by about 8 percentage points ( 7 percentage points in the model with controls) between 1997 and $2006 .{ }^{6}$

Table 4 shows the coefficient estimates for the change in computer use and task inputs in low- and medium-skilled occupations. Controlling for all relevant controls, the table clearly shows that the importance of all job tasks is generally lower for part-time workers. ${ }^{7}$ However, there has been a convergence in computer use, self-planning, and influencing tasks. To better identify the source of convergence in computer use we divided computer use into low computer use (Column 2) and high computer use (Column 3). In both estimates, the reference group is composed of workers who do not use computers in their job. The table shows that part-time workers' increase in computer use is driven by the increase in low-level computing tasks. ${ }^{8}$

\footnotetext{
${ }^{6}$ There could be a selection bias associated with the endogeneity of the decision to work on part-time basis (Manning and Petrongolo 2008). We have therefore also estimated the model after controlling for selection using standard Heckman sample selection correction techniques. Following Ermisch and Wright (1993) and Manning and Petrongolo (2008) we use the number of children and marital status as our exclusion restrictions. The model gives qualitatively similar results to the OLS model (see Table A3 in the appendix). For an extensive discussion on the endogeneity problem of part-time employment, see Fernández-Kranz and Rodríguez-Planas (2011).

${ }^{7}$ The descriptive statistics presented in Table 1 showed that physical tasks are more important for part-time workers. However, after including the controls the pattern changes.

${ }^{8}$ Similar results are obtained when estimating an ordered probit model to explain the changes in the level of computer use.
} 


\section{The source of convergence in wages, computer use, and job tasks}

Recent literature on the PTPP has shown that occupational segregation explains a large share of the PTPP (e.g. Connolly and Gregory 2008; Manning and Petrongolo 2008). As part-time workers sort into relatively low-skilled occupations, which pay lower hourly wages, they earn less than full-timers (Manning and Petrongolo 2008). To check to what extent changes in occupational segregation could have explained the decrease in the PTPP in the low- and medium-skilled occupations, we decompose the relative changes in wages into changes that are due to changes in average wages within occupations (i.e. how much of the difference can be explained by the possibility that part-time and full-time workers experience different wage changes within occupations) and those that are due to occupational shifts in the employment of part-time and full-time workers across occupations. For this purpose, we use the OaxacaRansom (1994) decomposition approach to apportion the change in the mean of wages over time for part-time and full-time workers. The decomposition of the mean shifts in wages between part-time and full-time workers is calculated as:

$$
\begin{gathered}
\left.\left.\left(\bar{W}_{2006}-\bar{W}_{1997}\right)_{F T}-\left(\bar{W}_{2006}-\bar{W}_{1997}\right)_{P T}=\left[U_{2006}-J_{1997}\right) \hat{\lambda}^{*}+J_{2006}\left(\hat{\lambda}_{2006}-\hat{\lambda}^{*}\right)+\left(J_{1997}\right)\left(\hat{\lambda}^{*}-\hat{\lambda}_{1997}\right)\right\}\right]_{F T}- \\
\left.\left[J_{2006}-J_{1997}\right) \hat{\lambda}^{*}+\left\{J_{2006}\left(\hat{\lambda}_{2006}-\hat{\lambda}^{*}\right)+\left(J_{1997}\right)\left(\hat{\lambda}^{*}-\hat{\lambda}_{1997}\right)\right\}\right]_{P T}
\end{gathered}
$$

where $\bar{W}_{t P T}$ and $\bar{W}_{t F T}$ are the average wage in time period $t$ for part-timers and full-timers, respectively. $J_{2006}$ and $J_{1997}$ are vectors containing occupational dummies and a constant term for the time periods 2006 and 1997, respectively. $\hat{\lambda}_{2006}$ and $\hat{\lambda}_{1997}$ are vectors with the slope parameters and the intercept for the time periods 2006 and 1997 , respectively. $\hat{\lambda}^{*}$ is the non-discriminatory coefficient vector. ${ }^{9}$ The terms $\left[\left(J_{2006}-J_{1997}\right) \hat{\lambda}^{*}\right]_{P T}$ and $\left[\left(J_{2006}-\right.\right.$ $\left.\left.J_{1997}\right) \hat{\lambda}^{*}\right]_{F T}$ represent the part of the change in wages that is explained by occupational

\footnotetext{
${ }^{9}$ The non-discriminatory coefficient is calculated by weighting the least squares estimates from the individual earnings equations as follows: $\hat{\lambda}^{*}=\Omega \hat{\lambda}_{2006}+(1-\Omega) \hat{\lambda}_{1997}$ where $\Omega=\left(j_{2006} J_{2006}+J_{1997} J_{1997}\right)^{-1}\left(j_{2006} J_{2006}\right)$ is the Oaxaca-Ransom weighting matrix.
} 
changes (i.e. across occupational changes), for part-time and full-time workers, respectively. The terms $\quad\left[J_{2006}\left(\hat{\lambda}_{2006}-\hat{\lambda}^{*}\right)+\left(J_{1997}\right)\left(\hat{\lambda}^{*}-\hat{\lambda}_{1997}\right)\right]_{P T}$ and $\quad\left[J_{2006}\left(\hat{\lambda}_{2006}-\hat{\lambda}^{*}\right)+\right.$ $\left.\left(J_{97}\right)\left(\hat{\lambda}^{*}-\hat{\lambda}_{1997}\right)\right]_{F T}$ are the portion of the change in wages that is unexplained by changes in occupations (within occupation changes) for part-time and full-time workers, respectively.

Table 5 summarizes the coefficients of the decomposition. The table shows that most of the relative improvement in the part-time pay takes place within occupations. About 81 percent $\left[(0.063 / 0.078)^{*} 100\right]$ of the change takes place within 2-digit occupations, and about 87 percent $\left[(0.068 / 0.078)^{*} 100\right]$ takes place within 3-digit occupations. This implies that a great deal of the decrease in the PTPP in low- and medium-skilled occupations over the period 1997-2006 is not due to changes in occupational segregation between part-time and full-time workers, but rather due to an improvement in the wages of part-timers compared to that of full-timers within occupations.

Similarly, the relative improvement in computer use and job tasks for part-time workers can be broken into two components: (1) changes in the task composition within occupations, (2) changes in the distribution of part-time and full-time workers across occupations. The technological change hypothesis predicts that changes in tasks take place within occupations due to changes in the production process (Black and Spitz-Oener 2010). To identify the source of the change in computer use and job tasks, we again use the Oaxaca-Ransom (1994) decomposition approach, replacing log wages in equation (3) by computer use and job tasks.

Table 6 shows the results of this decomposition. The first panel presents the results when we decompose changes in the part-time/full-time gap in computer use and job tasks to within and across 2-digit occupation changes. The second panel presents results when we look at changes within and across 3-digit occupations. ${ }^{10}$ Columns (1) and (2) show the within

\footnotetext{
${ }^{10}$ Estimating the changes in the job tasks over industry dummies gives qualitatively similar results.
} 
occupation changes for full-time and part-time workers, respectively. Column (3) shows the relative change within occupations between part-time and full-time workers by subtracting the changes within occupations for part-time workers (Column 2) from the changes within occupations for full-time workers (Column 1). Columns (4) and (5) show the changes in task inputs that are due to changes in the distribution of employment across occupations for fulltime and part-time workers, respectively. Column (6) shows the relative change across occupations between part-time and full-time workers by subtracting the occupational changes of part-time workers (Column 4) from the occupational changes of full-time workers (Column 5). Column (7) shows the total change in the difference in tasks of part-time and full-time workers. The table shows that the largest changes come from task changes within occupations; particularly for part-time workers. This is consistent with the idea that technological changes have recently changed the task composition of part-time workers more than that of full-time workers.

\section{Do relative changes in computer use and job tasks explain the convergence of the}

\section{PTPP?}

To estimate the extent to which convergence in computer use and job tasks between part-time and full-time workers explains the decrease in the PTPP, we use the decomposition approach by Juhn, Murphy, and Pierce (1991). ${ }^{11}$ The advantage of this decomposition technique over any other similar technique (e.g. Oaxaca-Ransom decomposition) is its ability to decompose the explained changes in the PTPP into changes that are due to relative task changes between part-time and full-time workers (changes in quantity), and changes that are

\footnotetext{
${ }^{11}$ To illustrate the relevance of the task-based approach in explaining the PTPP, we compare the PTPP remaining after controlling for job tasks to the PTPP that remains after accounting for occupational segregation. For this purpose, we estimate an earnings equation in which we regress log wage on a part-time dummy and insert job tasks, as an alternative to occupational dummies. As shown in Table A4 in the Appendix, job tasks relate to workers' wages and explain the PTPP almost equally well as do occupational dummies. The advantage of job tasks over occupational dummies, would be that when studying change over time, job tasks will not only capture changes across, but also within occupations.
} 
due to shifts in the wage returns to tasks (changes in prices). This technique has been used widely in the literature to study changes in gender wage differentials (e.g. Blau and Kahn 1992, 1997, Gupta et al. 2006). The change in the PTPP can initially be written as:

$$
D_{t} \equiv \bar{W}_{t}^{F T}-\bar{W}_{t}^{P T}=\left(X_{t}^{F T}-X_{t}^{P T}\right) \beta_{t}^{F T}+\left(\theta_{t}^{F T}-\theta_{t}^{P T}\right) \sigma_{t}^{F T}
$$

where $D_{t}$ is the difference in mean $\log$ wages $\left(\bar{W}_{t}\right)$ in year $t$ between full-time (FT) and part-time (PT) workers. $X_{t}^{F T}$ and $X_{t}^{P T}$ are vectors of mean computer use and job tasks in year $t$ for full-time and part-time workers, respectively. $\beta_{t}^{F T}$ is the OLS parameter estimates of computer use and job tasks at year $t$ for full-time workers. $\sigma_{t}^{F T}$ is the standard deviations of the residual of the wage equation of full-time workers. $\theta_{t}^{F T}$ is the standardized residual of the full-time wage regression, with mean 0 and variance $1 .{ }^{12} \theta_{t}^{P T}=\left(\bar{W}_{t}^{F T}-X_{t}^{P T} \beta_{t}^{F T}\right) / \sigma_{t}$, which reflects the wage a part-time worker would receive if her job tasks are rewarded at the same rate as a full-time worker's tasks are rewarded (deflated by the full-time worker's standardized residuals). Thus, the PTPP at a given point in time comprises an effect due to differences in observed tasks between part-time and full-time workers, weighted by the return received by full-time workers to these tasks, and an effect due to differences in the standardized residual, weighted by residual full-time inequality. Following the notation by Blau and Kahn (1992; 1994), the change in the PTPP can be rewritten as:

$$
\begin{aligned}
& D_{2006}-D_{1997}=\left(\Delta X_{2006}-\Delta X_{1997}\right) \beta_{1997}^{F T}+\Delta X_{2006}\left(\beta_{2006}^{F T}-\beta_{1997}^{F T}\right)+\left(\Delta \theta_{2006}-\Delta \theta_{1997}\right) \sigma_{2006}^{F T}+ \\
& \Delta \theta_{2006}\left(\sigma_{2006}^{F T}-\sigma_{1997}^{F T}\right)
\end{aligned}
$$

Where $\Delta$ represents the difference between full-timers and part-timers in the mean of the variable following. The first and second terms of the right-hand side of the equation reflect the portion of the change that is explained by changes in computer use and job tasks. The first term is the observed change in quantity of tasks, which reflects changes in the PTPP that are due to observed changes in part-time/ full-time differences in the inputs of computer

\footnotetext{
${ }^{12}$ This means that $\theta_{t}^{F T}=e_{t}^{F T} / \sigma_{t}^{F T}$ where $e_{t}^{F T}$ is the residual from the wage equation of full-timers in year $\mathrm{t}$.
} 
use and job tasks. The second term is the observed change in prices, which captures the contribution of changes in the rewards that the labour market attaches to computer use and job tasks of full-time workers. The third and fourth terms of the right hand side of equation (4) reflect the unexplained part in the Oaxaca-Ransom decomposition (1994). The change in the unexplained component can be divided in the "gap effect" (third term) which reflects the changes in the relative position of part-timers in the full-timers residual wage distribution and the "unobservable prices effect" (fourth term) which measures the change in the wage gap attributed to the change in the distribution of the full-time wage residuals, holding constant the mean part-time ranking in the full-time residual distribution.

Table 7 shows the estimates of the decomposition coefficients in low- and mediumskilled occupations. Column 1 shows the overall PTPP. Column 2 shows the portion of the PTPP that is explained by computer use and job tasks. Column 3 shows the unexplained portion of the PTPP. The table shows that the PTPP decreased from 26.7 log points in 1997 to $18.9 \log$ points in 2006 which means a 7.8 log-points decrease in the PTPP. More than half (53.8 percent) $\left[(0.042 / 0.078)^{*} 100\right]$ of the change in the PTPP can be explained by changes in computer use and job tasks. However, this portion is not solely due to an increase in part-timers' input of job tasks, it can also partly be due to changes in the task prices.

To investigate the share of the various tasks in the decrease of the PTPP, Table 8 shows the detailed estimates of the contribution of computer use and job tasks. The table divides the decomposition estimates of the explained portion of the decrease in the PTPP into a quantity effect (change in tasks inputs) and a price effect (change in task prices). Column 1 shows the overall explained contribution of computer use and job tasks in the decreased PTPP. Column 2 shows the portion of the contribution that is explained by changes in the quantity of computer use and job tasks. Column 3 is the portion that is explained by changes in the returns to computer use and job tasks. The table shows that more than 95 percent of the 
explained change in the decrease of the PTPP is due to changes in the overall quantity of computer use and job tasks $\left[(0.040 / 0.042)^{*} 100\right]$, while less than 5 percent of the decrease in the PTPP is due to changes in the overall prices of job tasks $[(0.002 / 0.040) * 100]$.

Estimates from Column 1 show that joint changes in the quantity and prices of computer use and reading and writing reduced the PTPP over time. While joint changes in the quantity and prices of influencing increased the PTPP over time. Changes in checking, physical tasks, self-planning, external communication, and math seem not to have significantly affected the change in the PTPP. Column 2 shows that particularly the convergence in the quantity of computer use between part-time and full-time workers explains a great deal of the decrease in the PTPP. While the convergence in the quantity of self-planning and influencing tasks between part-time and full-time workers explain only a small portion of the decrease in the PTPP. Column 3 shows that although the overall impact of changes in prices of tasks is small, there are large differences across the various job tasks. Changes in the prices of reading and writing lead to a convergence in the PTPP. Most of the PTPP-decreasing impact of reading and writing comes from changes in the prices. The changes in the prices of influencing and self-planning lead to a divergence in the PTPP. This divergence exceeds the effect of the convergence in the input of these tasks between part-time and full-time workers. This makes the overall impact of these tasks on the PTPP negative.

The results from Table 8 indicate that shifts in job tasks explain a great deal of the improvement in part-time workers' pay. However, this improvement in pay is not merely due to changes in the input of job tasks by part-timers compared to full-timers. The increase in part-time workers' relative pay could also be partly explained by changes in the wage returns to particular tasks. On one hand, as wage returns to particular tasks which are more often done by full-timers have decreased over time (or have relatively decreased for full-timers compared to part-timers), these tasks became less important in explaining the PTPP than they 
were in the past. Consequently, even when a gap between part-timers and full-timers in these job tasks remains, the change in the returns to these job tasks can partly explain the lower PTPP. Reading and writing is a typical example of such job tasks. On the other hand, as wage returns to particular tasks which are more often done by full-timers have increased over time (or have relatively increased for full-timers compared to part-timers), these tasks became more important in explaining the PTPP than they used to be in the past. Consequently, even when the gap between part-time and full-time workers in the quantity of these job task decreases, the change in the returns to these job tasks can negatively affect the PTPP. Influencing is an example of these job tasks.

\section{Conclusion}

This paper documents recent changes in the part-time pay penalty (PTPP) for female workers in the UK over the period 1997 to 2006 and investigates to what extent the decrease of the PTPP could be driven by relative changes in computer use and job tasks by full-time and part-time workers. We find a decrease in the PTPP over the period 1997-2006 for female workers in the low- and medium-skilled occupations in the UK. This decrease has been accompanied by a convergence in computer use, self-planning, and influencing tasks between part-time and full-time workers. The convergence in computer use explains a substantial part of the decrease in the PTPP. Furthermore, the change in the PTPP is affected by changes in wage returns to job tasks performed more intensively by full-timers. While the decreasing returns to reading and writing have decreased the PTPP, the increasing returns to influencing have increased the PTPP despite the convergence in the influencing task input between parttime and full-time workers. Relative changes in the input and prices of computer use and job tasks together explain more than 50 percent of the wage convergence between part-time and full-time workers in low- and medium-skilled occupations. 
This paper is the first to apply the task-based approach in studying the changes in the PTPP. However, our findings could not be interpreted in a causal way. There could be a reverse causality in which an increase in the wages of part-time workers (e.g. due to minimum wage legislations) has resulted in a decrease in the PTPP. ${ }^{13}$ This could have led employers to make better use of their part-time workers by involving them in higher levels of computer use and job tasks. However, Manning and Petrongolo (2008) have shown that the PTPP for female workers in the UK was not affected by the introduction of the National Minimum Wage in 1999.

The findings of our paper show that a task-based approach offers a highly relevant framework to analyse changes in the labour market position of part-time workers. A black box that remains is whether the changes we observe forced employers to hire part-time workers with higher educational attainments and/or better training, or because the same workers are doing more of computer use and other job tasks than they did in the past. Further studies should invest in panel data infrastructure to better identify the source of these changes in workers' job tasks.

\footnotetext{
${ }^{13}$ This could be the case because part-time workers are more likely to be employed in occupations with the lowest levels of pay. Therefore, any policy changes that aim at reducing wage inequality could improve the relative position of part-timers even if that change is not directly targeted on them (Manning and Petrongolo 2008).
} 


\section{References}

Acemoglu, D. (1998). Why do new technologies complement skills? directed technical change and wage inequality. Quarterly Journal of Economic, 113(4):1055-1089.

Acemoglu, D. and Autor D. (2011). Skills, tasks and technologies: Implications for employment and earnings. Handbook of labor economics, 4: 1043-1171.

Autor, D., Levy., F. and Murnane R. (2003). The skill content of recent technological Change: An empirical exploration. Quarterly Journal of Economics, 118(4): 1279-1333.

Black, S. E., and Spitz-Oener, A. (2010). Explaining women's success: technological change and the skill content of women's work. The Review of Economics and Statistics, 92(1): 187194.

Blau, F. D., and Kahn, L. M. (1992). The gender earnings gap: learning from international comparisons. The American Economic Review, 82(2): 533-538.

Blau, F. D., and Kahn, L. M. (1997). Swimming upstream: Trends in the gender wage differential in the 1980s. Journal of Labor Economics, 15(1): 1-42.

Booth, A. L., and van Ours, J. C. (2013). Part-time jobs: what women want?. Journal of Population Economics, 26(1): 263-283.

Connolly, S., and Gregory, M. (2008). Moving down: women's part-time work and occupational change in Britain 1991-2001. The Economic Journal, 118(526): F52-F76.

Connolly, S., and Gregory, M. (2009). The part-time pay penalty: earnings trajectories of British women. Oxford Economic Papers, 61 (Suppl. 1): i76-i97.

Elias, P., and McKnight A.(2001). Skill measurement in official statistics: recent developments in the UK and the rest of Europe. Oxford Economic Papers. 53(3): 508-540.

Ermisch, J. F., and Wright R.E.(1993). Wage offers and full-time and part-time employment by British women. Journal of Human Resources, 28(1): 111-133

Fernández-Kranz, D., and Rodríguez-Planas, N. (2011). The part-time pay penalty in a segmented labor market. Labour Economics, 18(5): 591-606.

Gallie, D., White M., Cheng Y., and Tomlinson M. (1998). Restructuring the employment relationship, Oxford: Oxford University Press.

Gallie, D. and Zhou, Y. (2011). The changing job skills of female part-time workers in Britain 1992-2006. Human Resource Management Journal, (21): 28-44.

Garicano, L., and Rossi-Hansberg E. (2006). Organization and inequality in a knowledge economy. Quarterly Journal of Economics, 121(4): 1383-1435.

Green, F. (2012). Employee involvement, technology and evolution in job skills: A taskbased analysis. Industrial and Labor Relations Review, 65(1): 36-67. 
Gupta, N. D., Oaxaca, R. L., \& Smith, N. (2006). Swimming upstream, floating downstream: Comparing women's relative wage progress in the United States and Denmark. Industrial and Labor Relations Review, 59(2):243-266.

Hirsch, B. T. (2005). Why do part-time workers earn less? the role of worker and job skills. Industrial and Labor Relations Review, 58(4):525-551.

Lindley, J. (2012). The gender dimension of technical change and the role of task inputs. Labour Economics, 19(4): 516-526.

Juhn, C., Murphy, K. M., and Pierce, B. (1991). Accounting for the slowdown in black-white wage convergence. Workers and Their Wages (ed.) M. H. Kosters, Washington, DC:AEI press: $107-143$.

Manning, A., and Petrongolo, B. (2008). The part-time pay penalty for women in Britain. The Economic Journal, 118(526): F28-F51.

Mumford, K., and Smith, P. N. (2009). What determines the part-time and gender earnings gaps in Britain: evidence from the workplace. Oxford Economic Papers, 61(Suppl. 1): i56i75.

Oaxaca, R. L., and Ransom, M. R. (1994). On discrimination and the decomposition of wage differentials. Journal of Econometrics, 61(1): 5-21.

Paull, G. (2008). Children and women's hours of work. The Economic Journal, 118(526): F8F27.

Snower, D. and Görlich D. J.( 2013). Multitasking and wages. IZA Working Paper. No. 7426, Bonn.

Spitz-Oener, A. (2006). Technical change, job tasks, and rising educational demands: looking outside the wage structure. Journal of Labor Economics, 24(2): 235-270 
Table 1: Differences in wages, job tasks, and background characteristics between part-time and full-time workers

\begin{tabular}{|c|c|c|c|c|c|c|}
\hline & \multicolumn{3}{|c|}{$\begin{array}{l}\text { Low and medium-skilled } \\
\text { occupations }\end{array}$} & \multicolumn{3}{|c|}{ High-skilled occupations } \\
\hline variable & FT & $\mathrm{PT}$ & FT-PT & FT & PT & FT-PT \\
\hline Log wage & 2.02 & 1.80 & $0.22 * * *$ & 2.54 & 2.62 & $-0.08 *$ \\
\hline Computer use & 0.83 & 0.62 & $0.20 * * *$ & 0.98 & 0.95 & $0.03 *$ \\
\hline Low computing & 0.79 & 0.59 & $0.20 * * *$ & 0.97 & 0.94 & $0.03 *$ \\
\hline High computing & 0.50 & 0.15 & $0.35 * * *$ & 0.93 & 0.77 & $0.16 * *$ \\
\hline Checking & 3.41 & 3.04 & $0.37 * * *$ & 3.47 & 3.30 & $0.17 * *$ \\
\hline Physical & 1.80 & 1.89 & -0.09 & 1.38 & 1.38 & -0.01 \\
\hline Problem solving & 2.75 & 2.28 & $0.48 * * *$ & 3.17 & 2.91 & $0.26 * * *$ \\
\hline Self-planning & 3.02 & 2.51 & $0.50 * * *$ & 3.63 & 3.40 & $0.23 * * *$ \\
\hline Influencing & 2.18 & 1.74 & $0.44 * * *$ & 3.04 & 2.84 & $0.21 * * *$ \\
\hline External comm. & 2.66 & 2.57 & $0.10 * * *$ & 2.92 & 2.67 & $0.25 * * *$ \\
\hline Read and write & 2.57 & 1.96 & $0.60 * * *$ & 3.16 & 2.96 & $0.20 *$ \\
\hline Math & 1.76 & 1.24 & $0.52 * * *$ & 2.22 & 1.89 & $0.33 * * *$ \\
\hline Age & 38.88 & 40.92 & $-2.04 * * *$ & 40.91 & 42.35 & $-1.44 *$ \\
\hline Married & 0.41 & 0.61 & $-0.20 * * *$ & 0.50 & 0.73 & $-0.23 * * *$ \\
\hline Number of children & 0.43 & 1.00 & $-0.57 * * *$ & 0.45 & 1.24 & $-0.80 * * *$ \\
\hline No qualification & 0.27 & 0.47 & $-0.20 * * *$ & 0.08 & 0.08 & 0.00 \\
\hline Qualification level 1 & 0.08 & 0.11 & $-0.03 *$ & 0.02 & 0.04 & $-0.02 *$ \\
\hline Qualification level 2 & 0.27 & 0.24 & 0.03 & 0.06 & 0.09 & -0.02 \\
\hline Qualification level 3 & 0.15 & 0.08 & $0.07 * * *$ & 0.11 & 0.10 & 0.01 \\
\hline Qualification level 4 & 0.23 & 0.09 & $0.14 * * *$ & 0.73 & 0.69 & 0.04 \\
\hline Work experience & 18.26 & 18.67 & -0.40 & 18.62 & 18.29 & 0.33 \\
\hline Trained & 0.62 & 0.44 & $0.17 * * *$ & 0.79 & 0.79 & 0.00 \\
\hline Observations & 1,700 & 1,304 & 3,004 & 614 & 164 & 778 \\
\hline
\end{tabular}

$* * * \mathrm{p}<0.01, * * \mathrm{p}<0.05, * \mathrm{p}<0.1$. Qualification level 1 corresponds to GCSE grade D or lower, (national exams normally taken at age 16). Qualification level 2 refers to GCSE grade A-C or vocational equaivalent. Qualification level 3 denotes A-level qualifications or their vocational equivalents. Qualification level 4 referes to tertiary diplomas, bachelor's degrees and above. 
Table 2: Change in part-time vs. full-time wages, job tasks, and background characteristics between 1997-2006

\begin{tabular}{|c|c|c|c|c|c|c|c|c|c|c|c|c|c|c|}
\hline \multirow[b]{3}{*}{ Variables } & \multicolumn{7}{|c|}{ Low and medium-skilled occupations } & \multicolumn{7}{|c|}{ Highly-skilled occupations } \\
\hline & \multicolumn{3}{|c|}{ FT } & \multicolumn{3}{|c|}{ PT } & \multirow{2}{*}{\begin{tabular}{|c|} 
Diff in diff. \\
$\Delta \mathrm{FT}-\Delta \mathrm{PT}$
\end{tabular}} & \multicolumn{3}{|c|}{ FT } & \multicolumn{3}{|c|}{ PT } & \multirow{2}{*}{\begin{tabular}{|l} 
Diff in diff \\
$\Delta \mathrm{FT}-\Delta \mathrm{PT}$
\end{tabular}} \\
\hline & 1997 & 2006 & $\Delta \mathrm{FT}$ & 1997 & 2006 & $\Delta \mathrm{PT}$ & & 1997 & 2006 & $\Delta \mathrm{FT}$ & 1997 & 2006 & $\Delta \mathrm{PT}$ & \\
\hline Log wage & 1.72 & 2.13 & $0.41 * * *$ & 1.45 & 1.94 & $0.48 * * *$ & $-0.08 *$ & 2.16 & 2.64 & $0.47 * * *$ & 2.39 & 2.68 & $0.29 * *$ & 0.19 \\
\hline Computer use & 0.78 & 0.84 & $0.06 * *$ & 0.49 & 0.67 & $0.18^{* * *}$ & $-0.12 * * *$ & 0.96 & 0.99 & $0.03^{*}$ & 0.90 & 0.96 & 0.07 & -0.04 \\
\hline Low computing & 0.73 & 0.81 & $0.08 * *$ & 0.48 & 0.64 & $0.17 * * *$ & $-0.09 *$ & 0.94 & 0.98 & $0.04 *$ & 0.88 & 0.96 & $0.08 *$ & -0.04 \\
\hline High computing & 0.44 & 0.53 & $0.08^{*}$ & 0.06 & 0.20 & $0.15^{* * *}$ & -0.07 & 0.86 & 0.95 & $0.09 *$ & 0.57 & 0.82 & $0.25^{*}$ & -0.16 \\
\hline Checking & 3.40 & 3.41 & 0.01 & 2.90 & 3.09 & $0.20 * * *$ & $-0.18 * * *$ & 3.46 & 3.47 & 0.01 & 3.25 & 3.31 & 0.06 & -0.05 \\
\hline Physical & 1.70 & 1.83 & $0.14^{*}$ & 1.76 & 1.94 & $0.18 * *$ & -0.04 & 1.49 & 1.35 & $-0.14 *$ & 1.48 & 1.36 & -0.12 & -0.02 \\
\hline Problem solving & 2.71 & 2.77 & 0.06 & 2.11 & 2.34 & $0.23 * *$ & $-0.17 *$ & 3.24 & 3.16 & -0.08 & 3.03 & 2.89 & -0.15 & 0.06 \\
\hline Self-planning & 2.88 & 3.07 & $0.19 * * *$ & 2.24 & 2.62 & $0.38 * * *$ & $-0.20^{*}$ & 3.56 & 3.64 & $0.08 *$ & 3.40 & 3.40 & 0.00 & 0.08 \\
\hline Influencing & 2.04 & 2.23 & $0.19 * * *$ & 1.50 & 1.84 & $0.34 * * *$ & $-0.14^{*}$ & 2.99 & 3.06 & 0.07 & 2.97 & 2.81 & -0.15 & 0.23 \\
\hline External comm. & 2.57 & 2.69 & $0.12 *$ & 2.41 & 2.63 & $0.22 * * *$ & -0.09 & 2.99 & 2.90 & -0.10 & 2.68 & 2.66 & -0.02 & -0.08 \\
\hline Read and write & 2.42 & 2.62 & $0.20 * * *$ & 1.77 & 2.04 & $0.27 * * *$ & -0.07 & 3.09 & 3.18 & 0.10 & 2.95 & 2.96 & 0.01 & 0.09 \\
\hline Math & 1.71 & 1.78 & 0.07 & 1.13 & 1.29 & $0.16^{*}$ & -0.09 & 2.34 & 2.19 & -0.15 & 2.03 & 1.86 & -0.18 & 0.02 \\
\hline Age & 37.08 & 39.53 & $2.46^{* * *}$ & 40.61 & 41.04 & 0.43 & $2.03^{*}$ & 38.59 & 41.48 & $2.89 * *$ & 40.52 & 42.74 & 2.22 & 0.67 \\
\hline Married & 0.44 & 0.40 & -0.03 & 0.72 & 0.57 & $-0.15^{* * *}$ & $0.12 * *$ & 0.51 & 0.49 & -0.02 & 0.76 & 0.72 & -0.04 & 0.02 \\
\hline Number of children & 0.42 & 0.44 & 0.02 & 1.06 & 0.98 & -0.08 & 0.10 & 0.51 & 0.43 & -0.08 & 1.45 & 1.20 & -0.25 & 0.17 \\
\hline No qualification & 0.29 & 0.27 & -0.02 & 0.57 & 0.44 & $-0.13 * * *$ & $0.11^{* *}$ & 0.07 & 0.08 & 0.01 & 0.10 & 0.07 & -0.03 & 0.04 \\
\hline Qualification level 1 & 0.07 & 0.08 & 0.01 & 0.09 & 0.12 & 0.03 & -0.02 & 0.03 & 0.02 & -0.02 & 0.00 & 0.05 & 0.05 & $-0.07 *$ \\
\hline Qualification level 2 & 0.35 & 0.24 & $-0.11 * * *$ & 0.23 & 0.24 & 0.01 & $-0.12 * *$ & 0.10 & 0.05 & $-0.04 *$ & 0.03 & 0.10 & 0.06 & $-0.11^{*}$ \\
\hline Qualification level 3 & 0.11 & 0.17 & $0.05 * *$ & 0.05 & 0.10 & $0.05 * *$ & 0.01 & 0.12 & 0.11 & -0.01 & 0.07 & 0.11 & 0.04 & -0.05 \\
\hline Qualification level 4 & 0.18 & 0.25 & $0.07 * *$ & 0.06 & 0.10 & $0.04 *$ & 0.03 & 0.68 & 0.74 & 0.06 & 0.79 & 0.67 & -0.13 & $0.19 *$ \\
\hline Work experience & 16.98 & 18.73 & $1.75^{* *}$ & 17.98 & 18.94 & $0.96^{*}$ & 0.79 & 16.54 & 19.14 & $2.60 * *$ & 15.28 & 18.94 & $3.66^{*}$ & -1.07 \\
\hline Trained & 0.60 & 0.63 & 0.03 & 0.40 & 0.46 & $0.06^{*}$ & -0.03 & 0.80 & 0.79 & -0.01 & 0.79 & 0.79 & 0.00 & -0.01 \\
\hline Observations & 455 & 1,245 & & 370 & 934 & & & 121 & 493 & & 29 & 135 & & \\
\hline
\end{tabular}

*** $\mathrm{p}<0.01, * * \mathrm{p}<0.05, * \mathrm{p}<0.1$ 
Table 3: OLS estimation of change in the PTPP over the period 1997-2006 for low- and medium-skilled occupations.

\begin{tabular}{|c|c|c|}
\hline VARIABLES & $\begin{array}{c}(1) \\
\text { Log wage }\end{array}$ & $\begin{array}{c}(2) \\
\text { Log wage } \\
\end{array}$ \\
\hline Part-timer & $\begin{array}{c}-0.267 * * * \\
(0.026)\end{array}$ & $\begin{array}{c}-0.095 * * * \\
(0.020)\end{array}$ \\
\hline Year 2006 & $\begin{array}{c}0.407 * * * \\
(0.020)\end{array}$ & $\begin{array}{c}0.363 * * * \\
(0.015)\end{array}$ \\
\hline Part-timer*Year 2006 & $\begin{array}{c}0.078 * * \\
(0.031)\end{array}$ & $\begin{array}{c}0.070 * * * \\
(0.023)\end{array}$ \\
\hline $\begin{array}{l}\text { Occupational dummies } \\
\text { Controls } \\
\text { Constant }\end{array}$ & $\begin{array}{c}\text { No } \\
\text { No } \\
1.722^{* * *} \\
(0.017)\end{array}$ & $\begin{array}{c}\text { Yes } \\
\text { Yes } \\
1.345^{* * *} \\
(0.101)\end{array}$ \\
\hline $\begin{array}{l}\text { Observations } \\
\text { R-squared }\end{array}$ & $\begin{array}{l}3,004 \\
0.267\end{array}$ & $\begin{array}{l}3,004 \\
0.621\end{array}$ \\
\hline \multicolumn{3}{|c|}{$\begin{array}{l}\text { Standard errors in parentheses } * * * \mathrm{p}<0.01, * * \mathrm{p}<0.05, * \mathrm{p}<0.1 \text {. Control } \\
\text { variables include worker's age, age squared, marital status, number of } \\
\text { children, level of education, training participation, work experience, } \\
\text { work experience squared, public or private sector, sector of industry } \\
\text { and occupational dummies. }\end{array}$} \\
\hline
\end{tabular}


Table 4: The change in job tasks and computer use for part-time workers relative to full-time workers over 1997-2006 in low and medium-skilled occupations.

\begin{tabular}{|c|c|c|c|c|c|c|c|c|c|c|c|}
\hline VARIABLES & $\begin{array}{c}(1) \\
\text { Computer } \\
\text { use }\end{array}$ & $\begin{array}{c}(2) \\
\text { Low-level } \\
\text { computer }\end{array}$ & $\begin{array}{c}\text { (3) } \\
\text { High_level } \\
\text { computer }\end{array}$ & $\begin{array}{c}\text { (4) } \\
\text { Checking }\end{array}$ & $\begin{array}{c}(5) \\
\text { Physical } \\
\text { tasks } \\
\end{array}$ & $\begin{array}{c}\text { (6) } \\
\text { Problem } \\
\text { solving } \\
\end{array}$ & $\begin{array}{c}\text { (7) } \\
\text { Self- } \\
\text { planning } \\
\end{array}$ & $\begin{array}{c}\text { (8) } \\
\text { Influencing }\end{array}$ & $\begin{array}{l}\text { (9) } \\
\text { External } \\
\text { comm. } \\
\end{array}$ & $\begin{array}{c}(10) \\
\text { Reading } \\
\text { and writing } \\
\end{array}$ & $\begin{array}{l}\text { (11) } \\
\text { Math }\end{array}$ \\
\hline Part-timer & $\begin{array}{c}-0.137 * * * \\
(0.025)\end{array}$ & $\begin{array}{c}-0.129 * * * \\
(0.028)\end{array}$ & $\begin{array}{c}-0.091 * * * \\
(0.029)\end{array}$ & $\begin{array}{c}-0.291 * * * \\
(0.070)\end{array}$ & $\begin{array}{c}-0.142 * * \\
(0.067)\end{array}$ & $\begin{array}{c}-0.290 * * * \\
(0.069)\end{array}$ & $\begin{array}{c}-0.356 * * * \\
(0.067)\end{array}$ & $\begin{array}{c}-0.374 * * * \\
(0.060)\end{array}$ & $\begin{array}{c}-0.168 * * \\
(0.068)\end{array}$ & $\begin{array}{c}-0.205 * * * \\
(0.061)\end{array}$ & $\begin{array}{c}-0.210 * * * \\
(0.066)\end{array}$ \\
\hline Year 2006 & $\begin{array}{c}0.056 * * * \\
(0.019)\end{array}$ & $\begin{array}{c}0.072 * * * \\
(0.022)\end{array}$ & $\begin{array}{l}0.045^{*} \\
(0.023)\end{array}$ & $\begin{array}{c}0.022 \\
(0.052)\end{array}$ & $\begin{array}{l}0.082^{*} \\
(0.050)\end{array}$ & $\begin{array}{c}0.003 \\
(0.052)\end{array}$ & $\begin{array}{l}0.097^{*} \\
(0.050)\end{array}$ & $\begin{array}{c}0.067 \\
(0.045)\end{array}$ & $\begin{array}{c}0.033 \\
(0.051)\end{array}$ & $\begin{array}{c}0.101 * * \\
(0.046)\end{array}$ & $\begin{array}{c}0.043 \\
(0.049)\end{array}$ \\
\hline Part-timer*Year 2006 & $\begin{array}{c}0.084 * * * \\
(0.028)\end{array}$ & $\begin{array}{c}0.066^{* *} \\
(0.031)\end{array}$ & $\begin{array}{c}0.037 \\
(0.032)\end{array}$ & $\begin{array}{c}0.124 \\
(0.077)\end{array}$ & $\begin{array}{c}0.086 \\
(0.074)\end{array}$ & $\begin{array}{c}0.107 \\
(0.076)\end{array}$ & $\begin{array}{c}0.162 * * \\
(0.074)\end{array}$ & $\begin{array}{c}0.161 * * \\
(0.066)\end{array}$ & $\begin{array}{l}0.130 * \\
(0.075)\end{array}$ & $\begin{array}{l}-0.001 \\
(0.067)\end{array}$ & $\begin{array}{c}0.023 \\
(0.072)\end{array}$ \\
\hline $\begin{array}{l}\text { Controls } \\
\text { Occupational dummies } \\
\text { Constant }\end{array}$ & $\begin{array}{c}\text { Yes } \\
\text { Yes } \\
0.536^{* * *} \\
(0.126)\end{array}$ & $\begin{array}{c}\text { Yes } \\
\text { Yes } \\
0.520 * * * \\
(0.141)\end{array}$ & $\begin{array}{c}\text { Yes } \\
\text { Yes } \\
0.378^{* *} \\
(0.148)\end{array}$ & $\begin{array}{l}\text { Yes } \\
\text { Yes } \\
-0.313 \\
(0.346)\end{array}$ & $\begin{array}{c}\text { Yes } \\
\text { Yes } \\
-0.576^{*} \\
(0.331)\end{array}$ & $\begin{array}{l}\text { Yes } \\
\text { Yes } \\
0.033 \\
(0.342)\end{array}$ & $\begin{array}{c}\text { Yes } \\
\text { Yes } \\
-1.053^{* * *} \\
(0.330)\end{array}$ & $\begin{array}{l}\text { Yes } \\
\text { Yes } \\
-0.006 \\
(0.297)\end{array}$ & $\begin{array}{l}\text { Yes } \\
\text { Yes } \\
-0.002 \\
(0.338)\end{array}$ & $\begin{array}{c}\text { Yes } \\
\text { Yes } \\
-0.603^{* *} \\
(0.303)\end{array}$ & $\begin{array}{l}\text { Yes } \\
\text { Yes } \\
-0.278 \\
(0.325)\end{array}$ \\
\hline $\begin{array}{l}\text { Observations } \\
\text { R-squared }\end{array}$ & $\begin{array}{l}3,004 \\
0.423 \\
\end{array}$ & $\begin{array}{l}2,618 \\
0.412 \\
\end{array}$ & $\begin{array}{l}1,174 \\
0.730 \\
\end{array}$ & $\begin{array}{l}3,004 \\
0.219 \\
\end{array}$ & $\begin{array}{l}3,004 \\
0.235 \\
\end{array}$ & $\begin{array}{l}3,004 \\
0.198 \\
\end{array}$ & $\begin{array}{l}3,004 \\
0.275 \\
\end{array}$ & $\begin{array}{l}3,004 \\
0.313 \\
\end{array}$ & $\begin{array}{l}3,004 \\
0.248 \\
\end{array}$ & $\begin{array}{l}3,004 \\
0.367 \\
\end{array}$ & $\begin{array}{l}3,004 \\
0.240 \\
\end{array}$ \\
\hline
\end{tabular}

Standard errors in parentheses $* * * \mathrm{p}<0.01,{ }^{* *} \mathrm{p}<0.05,{ }^{*} \mathrm{p}<0.1$. Control variables include worker's age, age squared, marital status, number of children, level of education, training

participation, work experience, work experience squared, public or private sector, sector of industry and occupational dummies. 
Table 5: Oaxaca-Ransom decomposition of the change in the PTPP over the period 1997-2006

\begin{tabular}{|c|c|c|c|c|c|c|c|}
\hline & $\begin{array}{c}(1) \\
\text { Within } \\
\text { FT } \\
\end{array}$ & $\begin{array}{c}(2) \\
\text { Within } \\
\text { PT } \\
\end{array}$ & \begin{tabular}{|c|}
$(3)$ \\
Within \\
FT- \\
within \\
PT \\
\end{tabular} & $\begin{array}{c}\text { Across } \\
\text { FT }\end{array}$ & $\begin{array}{c}\text { Across } \\
\text { PT }\end{array}$ & \begin{tabular}{|c|}
$(6)$ \\
Across \\
FT- \\
across \\
PT \\
\end{tabular} & $\begin{array}{c}\text { (7) } \\
\text { diff in } \\
\text { diff }^{*} \\
\end{array}$ \\
\hline 2 digit occupations & $\begin{array}{c}0.367 \\
(0.020)\end{array}$ & $\begin{array}{c}0.430 \\
(0.018)\end{array}$ & -0.063 & $\begin{array}{c}0.040 \\
(0.012)\end{array}$ & $\begin{array}{c}0.055 \\
(0.014)\end{array}$ & -0.015 & -0.078 \\
\hline 3 digit occupations & $\begin{array}{c}0.371 \\
(0.020)\end{array}$ & $\begin{array}{c}0.439 \\
(0.018)\end{array}$ & -0.068 & $\begin{array}{c}0.035 \\
(0.012)\end{array}$ & $\begin{array}{c}0.045 \\
(0.015)\end{array}$ & -0.010 & -0.078 \\
\hline
\end{tabular}

${ }^{*}$ A negative sign means a decrease in the PTPP. In terms of Equation 3:

(1) $=\left[J_{2006}\left(\hat{\lambda}_{2006}-\hat{\lambda}^{*}\right)+\left(J_{1997}\right)\left(\hat{\lambda}^{*}-\hat{\lambda}_{1997}\right)\right]_{F T},(2)=\left[J_{2006}\left(\hat{\lambda}_{2006}-\hat{\lambda}^{*}\right)+\left(J_{1997}\right)\left(\hat{\lambda}^{*}-\hat{\lambda}_{1997}\right)\right]_{P T},(3)=$

(1) $-(2),(4)=\left[\left(J_{2006}-J_{1997}\right) \hat{\lambda}^{*}\right]_{F T},(5)=\left[\left(J_{2006}-J_{1997}\right) \hat{\lambda}^{*}\right]_{P T},(6)=(4)-(5)$, and $(7)=(3)+(6)$ 
Table 6: Decomposition of the change in the task difference over the period 1997-2006

\begin{tabular}{|c|c|c|c|c|c|c|c|}
\hline & \begin{tabular}{|c}
$(1)$ \\
Within \\
FT
\end{tabular} & $\begin{array}{c}(2) \\
\text { Within PT }\end{array}$ & $\begin{array}{c}\text { (3) } \\
\text { Within FT- } \\
\text { Within PT }\end{array}$ & $\begin{array}{c}(4) \\
\text { Across } \\
\text { FT }\end{array}$ & $\begin{array}{c}\text { (5) } \\
\text { Across PT }\end{array}$ & $\begin{array}{c}6) \\
\text { Across FT- } \\
\text { across PT }\end{array}$ & $\begin{array}{c}\text { (7) } \\
\text { Diff in diff* }\end{array}$ \\
\hline \multicolumn{8}{|l|}{ A) 2 digit occupations } \\
\hline Computer use & $\begin{array}{c}0.043 \\
(0.003)\end{array}$ & $\begin{array}{c}0.143 \\
(0.026)\end{array}$ & -0.100 & $\begin{array}{c}0.02 \\
(0.012)\end{array}$ & $\begin{array}{c}0.039 \\
(0.018)\end{array}$ & -0.019 & $\begin{array}{l}-0.119 \\
(0.035)\end{array}$ \\
\hline Checking & $\begin{array}{l}-0.009 \\
(0.048)\end{array}$ & $\begin{array}{c}0.15 \\
(0.070)\end{array}$ & -0.159 & $\begin{array}{c}0.025 \\
(0.018)\end{array}$ & $\begin{array}{c}0.098 \\
(0.034)\end{array}$ & -0.073 & $\begin{array}{c}-0.232 \\
(0.083)\end{array}$ \\
\hline Physical & $\begin{array}{c}0.105 \\
(0.048)\end{array}$ & $\begin{array}{c}0.155 \\
(0.055)\end{array}$ & -0.050 & $\begin{array}{c}0.017 \\
(0.029)\end{array}$ & $\begin{array}{c}0.005 \\
(0.026)\end{array}$ & 0.012 & $\begin{array}{l}-0.038 \\
(0.082)\end{array}$ \\
\hline Problem solving & $\begin{array}{l}-0.009 \\
(0.050)\end{array}$ & $\begin{array}{c}0.102 \\
(0.064)\end{array}$ & -0.111 & $\begin{array}{c}0.068 \\
(0.020)\end{array}$ & $\begin{array}{c}0.12 \\
(0.027)\end{array}$ & -0.052 & $\begin{array}{l}-0.163 \\
(0.081)\end{array}$ \\
\hline Self-planning & $\begin{array}{c}0.109 \\
(0.051)\end{array}$ & $\begin{array}{c}0.251 \\
(0.065)\end{array}$ & -0.142 & $\begin{array}{c}0.076 \\
(0.024)\end{array}$ & $\begin{array}{c}0.127 \\
(0.028)\end{array}$ & -0.051 & $\begin{array}{l}-0.193 \\
(0.082)\end{array}$ \\
\hline Influencing & $\begin{array}{c}0.075 \\
(0.047)\end{array}$ & $\begin{array}{c}0.215 \\
(0.052)\end{array}$ & -0.140 & $\begin{array}{c}0.124 \\
(0.022)\end{array}$ & $\begin{array}{c}0.129 \\
(0.028)\end{array}$ & -0.005 & $\begin{array}{l}-0.145 \\
(0.075)\end{array}$ \\
\hline External communication & $\begin{array}{c}0.041 \\
(0.051)\end{array}$ & $\begin{array}{c}0.197 \\
(0.064)\end{array}$ & -0.156 & $\begin{array}{c}0.092 \\
(0.026)\end{array}$ & $\begin{array}{c}0.035 \\
(0.034)\end{array}$ & 0.057 & $\begin{array}{l}-0.099 \\
(0.085)\end{array}$ \\
\hline Read and write & $\begin{array}{c}0.099 \\
(0.047)\end{array}$ & $\begin{array}{c}0.096 \\
(0.052)\end{array}$ & 0.003 & $\begin{array}{c}0.076 \\
(0.026)\end{array}$ & $\begin{array}{c}0.143 \\
(0.037)\end{array}$ & -0.067 & $\begin{array}{c}-0.064 \\
(0.080)\end{array}$ \\
\hline Math & $\begin{array}{l}-0.007 \\
(0.051)\end{array}$ & $\begin{array}{c}0.069 \\
(0.052)\end{array}$ & -0.076 & $\begin{array}{c}0.062 \\
(0.024)\end{array}$ & $\begin{array}{c}0.058 \\
(0.026)\end{array}$ & 0.004 & $\begin{array}{l}-0.072 \\
(0.080)\end{array}$ \\
\hline B) 3 digit occupations & & & & & & & \\
\hline Computer use & $\begin{array}{c}0.05 \\
(0.004)\end{array}$ & $\begin{array}{c}0.124 \\
(0.005)\end{array}$ & -0.074 & $\begin{array}{c}0.013 \\
(0.012)\end{array}$ & $\begin{array}{c}0.058 \\
(0.019)\end{array}$ & -0.045 & $\begin{array}{l}-0.119 \\
(0.035)\end{array}$ \\
\hline Checking & $\begin{array}{c}0.001 \\
(0.049)\end{array}$ & $\begin{array}{c}0.17 \\
(0.070)\end{array}$ & -0.169 & $\begin{array}{c}0.014 \\
(0.021)\end{array}$ & $\begin{array}{c}0.078 \\
(0.037)\end{array}$ & -0.064 & $\begin{array}{c}-0.232 \\
(0.083)\end{array}$ \\
\hline Physical & $\begin{array}{c}0.114 \\
(0.048)\end{array}$ & $\begin{array}{c}0.184 \\
(0.055)\end{array}$ & -0.07 & $\begin{array}{c}0.009 \\
(0.032)\end{array}$ & $\begin{array}{c}-0.024 \\
(0.030)\end{array}$ & 0.033 & $\begin{array}{l}-0.038 \\
(0.082)\end{array}$ \\
\hline Problem solving & $\begin{array}{l}-0.003 \\
(0.050)\end{array}$ & $\begin{array}{c}0.122 \\
(0.064)\end{array}$ & -0.125 & $\begin{array}{c}0.062 \\
(0.022)\end{array}$ & $\begin{array}{c}0.1 \\
(0.030)\end{array}$ & -0.038 & $\begin{array}{c}-0.163 \\
(0.081)\end{array}$ \\
\hline Self-planning & $\begin{array}{c}0.077 \\
(0.052)\end{array}$ & $\begin{array}{c}0.235 \\
(0.066)\end{array}$ & -0.158 & $\begin{array}{c}0.109 \\
(0.026)\end{array}$ & $\begin{array}{c}0.144 \\
(0.030)\end{array}$ & -0.035 & $\begin{array}{c}-0.193 \\
(0.082)\end{array}$ \\
\hline Influencing & $\begin{array}{c}0.077 \\
(0.047)\end{array}$ & $\begin{array}{c}0.218 \\
(0.052)\end{array}$ & -0.141 & $\begin{array}{c}0.121 \\
(0.025)\end{array}$ & $\begin{array}{c}0.127 \\
(0.032)\end{array}$ & -0.006 & $\begin{array}{l}-0.145 \\
(0.075)\end{array}$ \\
\hline External communication & $\begin{array}{c}0.011 \\
(0.052)\end{array}$ & $\begin{array}{c}0.177 \\
(0.062)\end{array}$ & -0.166 & $\begin{array}{c}0.122 \\
(0.029)\end{array}$ & $\begin{array}{c}0.055 \\
(0.041)\end{array}$ & 0.067 & $\begin{array}{l}-0.099 \\
(0.085)\end{array}$ \\
\hline Read and write & $\begin{array}{c}0.077 \\
(0.048)\end{array}$ & $\begin{array}{c}0.118 \\
(0.053)\end{array}$ & -0.041 & $\begin{array}{c}0.098 \\
(0.028)\end{array}$ & $\begin{array}{c}0.122 \\
(0.039)\end{array}$ & -0.024 & $\begin{array}{l}-0.064 \\
(0.080)\end{array}$ \\
\hline Math & $\begin{array}{l}-0.018 \\
(0.051)\end{array}$ & $\begin{array}{c}0.007 \\
(0.053)\end{array}$ & -0.025 & $\begin{array}{c}0.073 \\
(0.028)\end{array}$ & $\begin{array}{c}0.12 \\
(0.031)\end{array}$ & -0.047 & $\begin{array}{c}-0.072 \\
(0.080)\end{array}$ \\
\hline
\end{tabular}

* A negative sign means improvement in part-timers' task input relative to full-timers. In terms of Equation 5:

(1) $=\left[J_{2006}\left(\hat{\lambda}_{2006}-\hat{\lambda}^{*}\right)+\left(J_{1997}\right)\left(\hat{\lambda}^{*}-\hat{\lambda}_{1997}\right)\right]_{F T},(2)=\left[J_{2006}\left(\hat{\lambda}_{2006}-\hat{\lambda}^{*}\right)+\left(J_{1997}\right)\left(\hat{\lambda}^{*}-\hat{\lambda}_{1997}\right)\right]_{P T},(3)=(1)-(2),(4)=$ $\left[\left(J_{2006}-J_{1997}\right) \hat{\lambda}^{*}\right]_{F T},(5)=\left[\left(J_{2006}-J_{1997}\right) \hat{\lambda}^{*}\right]_{P T},(6)=(4)-(5)$, and $(7)=(3)+(6)$ 
Table 7: The The Juhn-Murphy-Pierce decomposition of the PTPP in low and medium-skilled occupations

\begin{tabular}{lc|c|c}
\hline & $(1)$ & $(2)$ & $(3)$ \\
& Raw differential & Explained differential & Unexplained differential \\
\hline & & & \\
PTPP 1997 & 0.267 & 0.172 & 0.094 \\
PTPP 2006 & 0.189 & 0.130 & 0.058 \\
& & & -0.036 \\
\hline
\end{tabular}

Estimates are obtained from regressions of log wages on computer use as well as job tasks. The change in the PTPP is calculated as $\left(\mathrm{W}^{\mathrm{FT}}-\mathrm{W}^{\mathrm{PT}}\right)_{2006}-\left(\mathrm{W}^{\mathrm{FT}}-\mathrm{W}^{\mathrm{PT}}\right)_{97}$. Therefore, a positive sign indicates an increase in the PTPP, and a negative sign indicates a decrease in the PTPP.

Table 8: The contribution of computer use and job tasks in the explained part of the PTPP in low and medium-skilled occupations

\begin{tabular}{lccc}
\hline & $\begin{array}{c}(1) \\
\text { Overall explained } \\
\text { changes }\end{array}$ & $\begin{array}{c}(2) \\
\text { Task changes } \\
\text { (Quantity effects) }\end{array}$ & $\begin{array}{c}(3) \\
\text { Task Price changes } \\
\text { (Price effect) }\end{array}$ \\
\hline Computer use & -0.018 & -0.024 & 0.006 \\
Checking & 0.003 & 0.002 & 0.002 \\
Physical & 0.001 & 0.003 & -0.002 \\
Problem solving & -0.006 & -0.004 & -0.002 \\
Self-planning & 0.004 & -0.007 & 0.011 \\
Influencing & 0.011 & -0.007 & 0.018 \\
External comm. & 0.001 & 0.003 & -0.003 \\
Read and write & -0.034 & -0.006 & -0.028 \\
Math & -0.004 & -0.001 & -0.004 \\
\hline Total & -0.042 & -0.040 & -0.002 \\
\hline
\end{tabular}

Overall explained change (1)= Task changes (2) + Task price changes(3). A positive sign indicates an increase in the PTPP, and a negative sign indicates a decrease in the PTPP. 


\section{Appendix A:}

Table A1: The list of the job tasks in the UK Skills Survey (Green 2012)

\section{Reading and writing}

Reading written information, e.g. forms, notices or signs

Reading short documents e.g. Letters or memos

Reading long documents e.g. Long reports, manuals, etc

Writing material such as forms, notices or signs

Writing short documents, e.g. Letters or memos.

Writing long documents with correct spelling/grammar.

\section{Math}

Adding, subtracting, multiplying or dividing numbers

Calculations using decimals, percentages or fractions?

More advanced mathematical or statistical procedures.

\section{External comm.}

Knowledge of particular products or services

Selling a product or service.

Counselling, advising or caring for customers or clients.

Dealing with people.

\section{Influencing others}

Instructing, training or teaching people

Persuading or influencing others.

Making speeches or presentations.

Planning the activities of others.

Listening carefully to colleagues.

\section{Self-planning}

Planning your own activities.

Organizing your own time.

Thinking ahead.

\section{Problem solving}

Spotting problems or faults

Working out the cause of problems or faults

Thinking of solutions to problems 
Analysing complex problems in depth

\section{Physical tasks}

Physical strength e.g., carry, push or pull heavy objects

Work for long periods on physical activities

Skill or accuracy in using your hands or fingers

Use or operate tools, equipment or machinery

\section{Checking}

Noticing when there is a mistake

Checking things to ensure that there are no errors

Paying close attention to detail 


\section{Level 1:}

Elementary trades, plant and storage related occupations.

Elementary administration and service occupations.

Textiles, printing and other skilled trades.

Level 2:

Administrative occupations.

Secretarial and related occupations.

Caring personal service occupations.

Leisure and other personal service occupations.

Sales occupations.

Customer service occupations.

Process, plant and machine operatives.

Transport and mobile machine drivers and operatives.

Level 3:

Managers and proprietors in agriculture and services.

Science and technology associate professionals.

Health and social welfare associate professionals.

Protective service occupations

Culture, media and sports occupations.

Business and public service associate professionals.

Skilled agricultural trades.

Skilled metal and electrical trades.

Skilled construction and building trades.

\section{Level 4:}

Corporate managers.

Science and technology professionals.

Health professionals.

Teaching and research professionals.

Business and public service professionals 
Table A3: Heckman selection procedure to estimate changes in the PTPP over the period 1997-2006

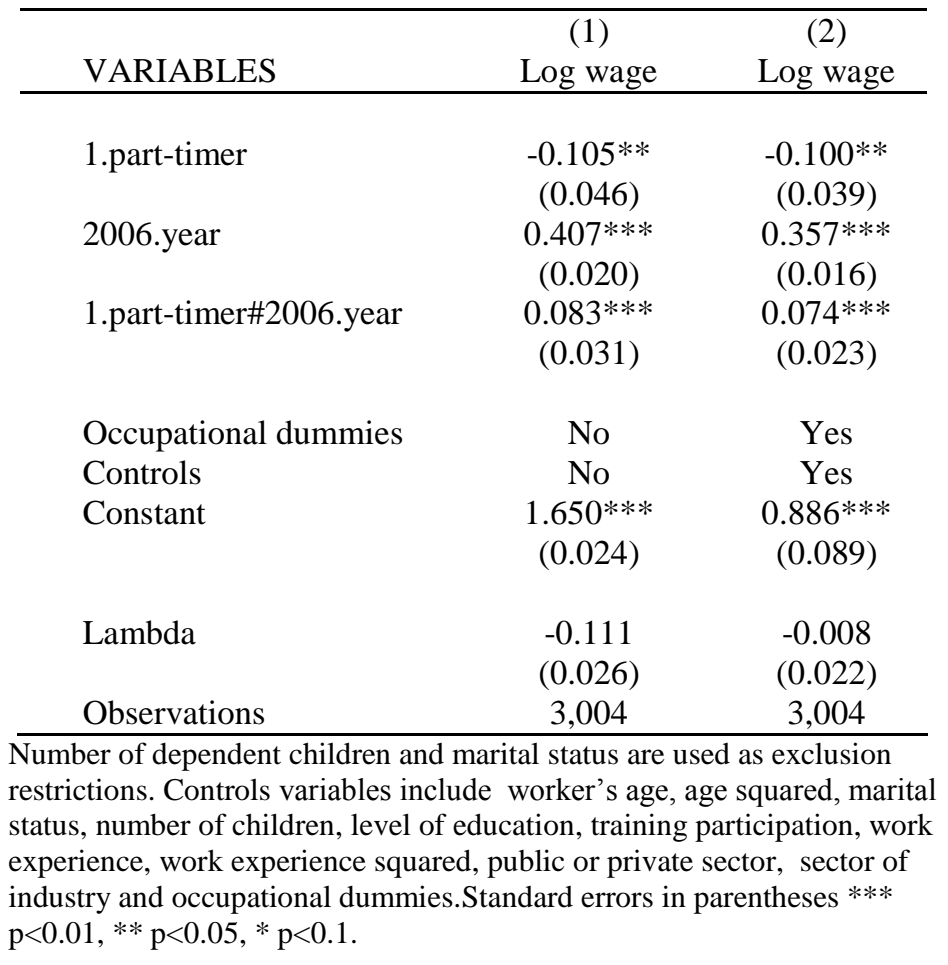


Table A4: OLS estimates for the part-time pay penalty

\begin{tabular}{|c|c|c|c|c|}
\hline & \multicolumn{4}{|c|}{ Log wage } \\
\hline & (1) & (2) & (3) & (4) \\
\hline part-timer & $\begin{array}{c}-0.218 * * * \\
(0.016)\end{array}$ & $\begin{array}{c}-0.071 * * * \\
(0.014)\end{array}$ & $\begin{array}{c}-0.069 * * * \\
(0.014)\end{array}$ & $\begin{array}{c}-0.064 * * * \\
(0.014)\end{array}$ \\
\hline Checking & & & & $\begin{array}{l}-0.002 \\
(0.009)\end{array}$ \\
\hline Physical tasks & & & & $\begin{array}{c}-0.045^{* * *} \\
(0.007)\end{array}$ \\
\hline Problem solving & & & & $\begin{array}{c}0.006 \\
(0.010)\end{array}$ \\
\hline Self-planning & & & & $\begin{array}{c}0.052 * * * \\
(0.009)\end{array}$ \\
\hline Influencing & & & & $\begin{array}{c}0.101 * * * \\
(0.010)\end{array}$ \\
\hline External comm. & & & & $\begin{array}{c}-0.061 * * * \\
(0.008)\end{array}$ \\
\hline read and write & & & & $\begin{array}{c}0.056^{* * * *} \\
(0.010)\end{array}$ \\
\hline Math & & & & $\begin{array}{c}-0.016^{* *} \\
(0.008)\end{array}$ \\
\hline No computer use & & & & Reference \\
\hline Low-level computer & & & & $0.239 * * *$ \\
\hline High-level computer & & & & $\begin{array}{c}(0.019) \\
0.348 * * * \\
(0.027)\end{array}$ \\
\hline Controls & No & No & No & No \\
\hline Occupations & No & 2-digit & 3-digit & No \\
\hline Constant & $\begin{array}{c}2.019 * * * \\
(0.010)\end{array}$ & $\begin{array}{c}2.264 * * * \\
(0.046)\end{array}$ & $\begin{array}{c}2.264 * * * \\
(0.046)\end{array}$ & $\begin{array}{c}1.799 * * * \\
(0.018)\end{array}$ \\
\hline Observations & 3,004 & 3,004 & 3,004 & 3,004 \\
\hline R-squared & 0.061 & 0.356 & 0.368 & 0.315 \\
\hline
\end{tabular}

Standard errors in parentheses $* * * \mathrm{p}<0.01,{ }^{* *} \mathrm{p}<0.05, * \mathrm{p}<0.1$ 